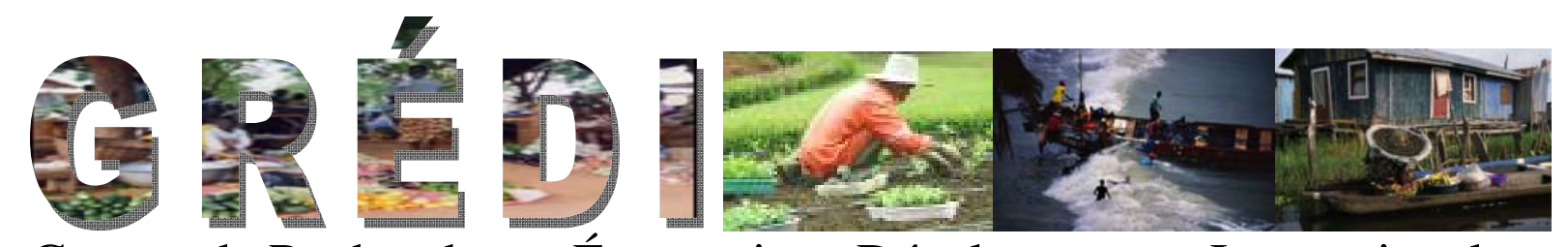

Groupe de Recherche en Économie et Développement International

Cahier de recherche / Working Paper

$07-10$

\title{
Electricity Reforms in Mali: \\ A Macro-Micro Analysis of the Effects on Poverty and Distribution
}

Dorothée Boccanfuso

Antonio Estache

Luc Savard 


\title{
Electricity Reforms in Mali: A Macro-Micro Analysis of the Effects on Poverty and Distribution
}

\author{
DOROTHÉE BOCCANFUSO, ANTONIO ESTACHE, AND LUC SAVARD
}

MAY 2006

\begin{abstract}
This paper uses a computable general equilibrium (CGE) microsimulation model to explore the distributional and poverty-related effects of price reform in the electricity sector of Mali, a poor country in West Africa. In the first part of the paper we analyze the distribution of electricity in Mali by income deciles, showing that few poor households are connected to the electricity grid. We then apply a sequential CGE microsimulation model to track the transmission mechanisms between increases in electricity prices and changes in poverty and inequality among different household groups. Our results show that direct price increases have a minimal effect on poverty and inequality, whereas the general equilibrium effects of such increases are quite strong and negative. The compensating policies we tested do not help those who lose from the pricing reform. In fact they amplify the negative effects.
\end{abstract}

Keyword: computable general equilibrium model, microsimulation, poverty analysis, income distribution, privatization.

JEL : D 5 8, D31, I32, L33 


\section{Introduction}

Mali's experience with utility reform since 1997 provides an interesting example of the problems and potential of privatization in the context of a development strategy designed to reduce poverty. Few such experiments have been conducted in Africa, compared with other regions. In Latin America, for example, widespread privatization of water utilities - intended to improve efficiency and cost recovery - has been associated with large price increases that have created enormous social and political tensions (Estache 2005a). In Africa, the privatization process has been more sluggish (Estache 2005b). Only recently has evidence begun to emerge on the effects of reforms in the few African countries that have followed Latin America's lead. By exploring the evidence from Mali, this paper provides an early assessment of the impact of utility reforms in Africa.

Since 1997 Mali’s government has shown a strong will to fight poverty. Indeed, poverty has become the focus of all the country's development policies. A national anti-poverty strategy (Stratégie nationale de lutte contre la pauvreté, SNLP) was adopted in September 1998, followed in May 2002 by a "strategic framework for the struggle against poverty (Cadre stratégique de lutte contre la pauvreté, CSLP). These medium- and long-term steps, widely discussed with the international community, have been used to support some dramatic reforms in the delivery of infrastructure services.

We use a computable general equilibrium (CGE) model to analyze the impact of pricing reforms on poor households in Mali. Macroeconomic assessment is important because utility reforms typically affect other economic markets (for labor, investment, and savings, for example) that can have a significant effect on poverty and on the welfare of the poor. An economy-wide analysis can capture these feedback effects, particularly if it uses a multi-agent, multi-commodity approach. CGE models are very useful for simulating the economic and social impact of reforms when based on a detailed modeling of the socioeconomic structure of an economy in the form of a social accounting matrix (SAM), with its multisectoral disaggregation. ${ }^{1}$ How deep the analysis can go depends on data availability. ${ }^{2}$

Although CGE models have been around for at least 25 years, few scholars have used them to analyze the effects of reforms of public infrastructure services. Chisari, Estache, and Romero (1999), Benitez, Chisari, and Estache (2003), and Navajas (2000) did so for Argentina. Andersen and Faris (2002) did so for natural gas in Bolivia. And Löfgren and others (1997) did so for rural Morocco. But those are among the very few published papers on the topic. These contributions addressed the distributional issues of reform, but at a highly aggregated level (because good household data were scarce). The data have improved since the late 1990s, enabling a growing number of researchers to develop and apply macromicro CGE modeling in developed and developing economies alike. Poverty analysis has been a central objective of this research. In this paper, we rely on the CGE microsimulation sequential (CGE-MSS) approach presented in Chen and Ravallion (2004) ${ }^{3}$. We will present other approaches and justify our choice subsequently.

\footnotetext{
${ }^{1}$ See chapter 5 in Decaluwé et al (2001).

${ }^{2}$ The potential of these models was identified early on, as seen in Dervis, de Melo, and Robinson (1982). For a review of the history of CGEs see Hertel and Reimer (2004).

${ }^{3}$ Sometimes referred to as a CGE micro-accounting approach, for our concern here.
} 
The available data were in the form of an input-output table with 17 productive sectors with 2001 data. In this preliminary version of the SAM, the utilities were aggregated. ${ }^{4}$ We had to disaggregate them in order to analyze policies associated with privatization in individual sectors. Information from Electricity du Mali (EDM) was used to disaggregate the water and electricity sector from the original input-output sector (electricity-gas-water). The end result was a SAM with 20 production sectors with three specific utilities (Water, Electricity and Telecom). The next step was to link the micro-household data-4966 households from the 2001 Enquête malienne sur l'évaluation de la pauvreté (EMEP) survey - to the SAM. We modify the income and expenditure structures for the households based on the nomenclature of the SAM.

Mali's utilities sectors are profiled in the next section. In section 3 we explore the distributional aspects of these sectors, followed by a discussion of the methodologies used in the impact analysis, a description of the simulation, and a presentation of our model results. We complete the poverty analysis after applying the complete model (sections 4 and 5). Section 6 provides conclusions and recommendations.

\section{Electricity reforms in Mali}

Mali's public utility operator, Energie du Mali (EDM), was established in 1960, shortly after independence, with capital from the Malian government and the French aid agency (AFD). It offered both water and electricity services. Initially, EDM operated small diesel-fired generating plants in Bamako and several secondary cities. The cost of producing electricity was very high, because low levels of power consumption prevented economies of scale and because of the high cost of transporting diesel fuel from Ivory Coast and Senegal to landlocked Mali. This encouraged the Malian government to develop hydro power. The first small hydro plant, at Sotuba, began producing power in 1967. Sotuba reached peak capacity by the mid-1970s, but a new dam at Sélingué began generating power in 1980. Sélingué's capacity was exceeded by the early 1990s, which led to the construction of a third hydro plant at Manantali.

Throughout this period, EDM suffered from the same problems that afflicted other African utilities: mismanagement and political interference. In 1986, EDM adopted a performance contract to try to improve operations. The experiment did not last long: a coup brought down the government two years into the contract. The return of democracy in 1992 led to a new round of efforts to improve sector management, but only after a period of frequent reshufflings of the cabinet had passed.

In 1994, the government solicited bids to manage the utility. The international competition was won by a French-Canadian consortium led by the Société d’Aménagement Urbain et Rural (SAUR) and including Hydro Québec and Électricité de France (EDF). Each member of the consortium was responsible for certain functions at EDM, such as billing and collections, human relations, and production and distribution of electricity and water. The management contract was to extend four years, beginning in January 1995. The contract went well for the first year or two, after which relationships between the foreign managers and the Malian board of directors deteriorated. In March 1998, the board cancelled the contract. Another two years passed before another attempt to improve the sector was made.

\footnotetext{
${ }^{4}$ For example, the water and electrical utilities were in the same account, and telecommunications was aggregated with transport.
} 
In 2000, the Malian government prepared a 20-year concession contract that specified in detail the obligations of the new operator. In the first five years, the operator would be required to increase the number of electricity customers from 80,000 to 143,000 and the number of water customers from 60,000 to 80,000 . By 2020 , it was to have 300,000 electricity customers and 195,000 water customers. The contract would also require the operator to increase the number of urban centers provided with electricity from 34 to 97 by 2020. The associated investment needs were about 20 billion CFA francs per year. The contract specified a formula for tariff adjustments until a regulator, created by the same reform, could begin to enforce a price-cap approach. The Ministry of Mines, Energy, and Water retained responsibility for technical supervision of EDM.

SAUR was the highest bidder for the proffered 60 percent of the stock in the company. (The government retained ownership of the other 40 percent.) SAUR offered six times more than the next qualified bid. The concession was signed in November 2000 and went into effect the next month. This is the management reflected in the modeling of the sector as described in section 4 .

\section{The distribution of electricity in Mali}

We used the EMEP survey to analyze trends in the supply of water and electricity to Mali's households by income quintiles. Only 2.75 percent of the poorest 30 percent of households are connected to the electricity grid, compared with 72.6 percent for the three richest deciles (table 1). The connection rate for the two top deciles (34.5 percent and 30.4 percent) is much higher than for the poorest groups ( 0.3 percent and 0.4 percent). The low connection rate of the poor is partly explained by the fact that most poor households live in rural areas, beyond the reach of the grid.

Table 1 Household electricity access by decile

\begin{tabular}{lccc}
\hline Decile & $\begin{array}{c}\text { Number (percentage) of } \\
\text { households without electric } \\
\text { meter } \\
\text { (89.5 percent of all } \\
\text { households) }\end{array}$ & $\begin{array}{c}\text { Number (percentage) of } \\
\text { households with electric meter } \\
\text { (10.5 percent of all } \\
\text { households) }\end{array}$ & Total \\
\hline 1 (poorest) & $91,562(9.38)$ & $317(0.28)$ & $91,879(8.42)$ \\
2 & $127,935(13.1)$ & $634(0.55)$ & $128,569(11.78)$ \\
3 & $107,813(11.04)$ & $2,211(1.92)$ & $110,024(10.08)$ \\
4 & $111,009(11.37)$ & $2,601(2.26)$ & $113,610(10.41)$ \\
5 & $114,745(11.75)$ & $7,578(6.6)$ & $122,323(11.21)$ \\
6 & $101,475(10.39)$ & $7,333(6.38)$ & $108,808(9.97)$ \\
7 & $97,122(9.95)$ & $10,812(9.41)$ & $107,934(9.89)$ \\
8 & $94,822(9.71)$ & $21,024(18.3)$ & $115,846(10.62)$ \\
9 & $67,093(6.87)$ & $29,345(25.54)$ & $96,438(8.84)$ \\
All & $62,661(6.42)$ & $33,031(28.75)$ & $95,692(8.77)$ \\
\hline
\end{tabular}

Source: Authors' computation based on Enquête Malienne d'Évaluation de la Pauvreté (EMEP), 2001. 


\section{A CGE microsimulation applied to Mali}

Since the late 1990s researchers have been using CGE to analyze impact of policy reforms on poverty and income distribution. Three main categories of these models have been used during this period; the representative household approach (RH), the integrated multi-household (IMH) approach and the multi-household sequential approach (MHS).

The CGE-RH approach divides households into groups, choosing a representative household for each group and using that representative household in the CGE model. Results of the CGE model are then used by using changes in the income of the representative households and applying the variation to all households in each household of the representative group. This assumption does not allow the analyst to take into account within-group changes in income distribution, even though studies (Huppi and Ravallion 1991 and Savard 2005, for example) have shown that such changes can be greater than between-group inequality changes. This is true both for the static measure and for variations following policy simulations. Savard (2005), demonstrated that the results of poverty and income distribution analysis can be completely reversed by taking into account within-group distributional effects.

To solve this problem, a second approach, was proposed by Decaluwé, Dumont, and Savard (1999) and applied by Cogneau and Robilliard (2000), Gørtz, Neilsen, and Rutherford (2000), and Cockburn (2001), is the CGE integrated multi-household approach (CGE-IMH). This method incorporates a large number of households from a household survey (and sometimes all of them) into the CGE model. The approach takes into account within-group distributional effects and has the further advantage of providing coherence between the micro and macro parts of the model, but at a cost. First, data reconciliation can be very problematic (Rutherford, Tarr, and Shepotylo 2005); second, numerical resolution can be challenging (Chen and Ravallion, 2004).

The third approach is referred to as the CGE micro-simulation sequential method (MSS) and could be subdivided into two variants. The first one, macro-accounting, is formally presented by Chen and Ravallion (2004) and extensively applied in recent years. The second one, proposed by Bourguignon, Robilliard and Robinson (2005), consists in integrating at an individual level rich micro behavior observed at a household level such as consumption or labor supply. The general idea of the MSS approach is that a CGE module feeds market and factor price changes into a micro-simulation household model. The main criticism levelled at this approach is that the micro-feedback effect is not fully taken into account : the question has been raised in two literature reviews of macro-micro modeling for poverty analysis (Hertel and Reimer (2004) as well as Bourguignon and Spadaro (2005). However, Bourguignon and Savard (2007) found that the loss of information associated to using the MSS approach can be relatively small and policy conclusions were robust between the two approaches ${ }^{5}$.

The last two approaches (IMH, MSS) allow for rich analysis of income distribution and poverty because they include a large number of households in the modeling exercise. This in turn allows the modeler to apply poverty and income distribution measures and indexes following policy simulations. As was mentioned the IMH approach is the soundest on theoretical basis. However, with this approach, it is

\footnotetext{
${ }^{5}$ Bourguignon and Savard (2007) comparative analysis between the IMH and MSS approaches was applied on the Filipino economy. In there study, the labor supply was endogenous and the largest portion of the gap in the results obtained from the two approaches came from the labor supply. The labor supply will be held constant in our application.
} 
necessary to construct a balanced sub-matrix for household accounts in a standard social accounting matrix. On the other, with the CGE-MSS approach, the household income and expenditure do not require balancing. This gain in flexibility comes from the fact that the micro module is solved sequentially and that we use price percentage changes to link the CGE module to the micro household module. This constraint has led us to select the CGE-MSS approach for our analysis. We will refer to the household sub matrix database as the household module. The model constructed for this paper is the first CGE singlecountry model applied to Mali. ${ }^{6}$

Before describing the model in detail it is important to highlight the links between economic policy and household welfare. Economic policies and external shocks are transmitted to household incomes through mechanisms such as variations in prices of consumer goods and services and, more significantly, in the return on factors of production. Between the policy reform and the appearance of price changes, many interactions take place between production sectors as factors relocate. The structure of the economy, the behaviors of economic actors, and rules of macroeconomic closure also play important roles. Hertel and Reimer (2004) provide an interesting discussion on these issues as well as McCulloch et al (2002). To capture the impact of policies on the welfare of individual households, it is important to incorporate details of the question at hand, in this case Mali's utilities and the structure and functioning of the nation's overall economy.

\section{CGE module}

Our CGE component of our model (referred to as CGE module hereafter) is based on the EXTER model of Decaluwé et al (2001), with some adjustments, which we will describe after presenting the main features of EXTER. Production is determined using a three-level system: total production of the sector $(X S)$ is made up of fixed value-added shares (VA) and intermediate consumption (CI), as generally assumed in standard CGE modeling. The relationship determining the level of VA is a Cobb-Douglas production function between composite labor $(L D)$ and capital $(K D)$. Producers minimize their cost of producing VA subject to the Cobb-Douglas function. Optimal labor demand equations are derived from this minimization process. Labor is then decomposed into skilled and unskilled labor, with the combination of these two factors being determined by a constant elasticity of substitution (CES) function, once again through a process of cost minimization. This assumption implies that changes in the relative wages of the two types of labor will lead the producer to modify the ratio between the two groups of workers, subject to constraints on substitution linked to his production capacities. A sector-specific elasticity of substitution is used to reflect differences among sectors in determining the mix of skilled and unskilled labor.

We assumed that capital is partly fixed within sectors, as it takes considerable time in Mali to convert capital for use in a new production sector following a policy shock. Intermediate consumption was modeled as fixed shares from the input/output ratios calculated from the data in the SAM. This is a common practice with this type of model.

As noted earlier, our model for Mali covers 20 production sectors, including water, electricity, and telecommunications (plus an informal water-producing sector). None of the three utility sectors was

\footnotetext{
${ }^{6}$ Decaluwé, Dissou, and Patry (2001) constructed a multi-country CGE model to analyze reforms of the West African Monetary and Economic Union (UEMOA). Boccanfuso and Savard (2007) used a modified version of this model to analyze agricultural subsidies reform in Mali.
} 
disaggregated in the input-output table used to construct our SAM. We assumed that the sectors were subject to price controls (exogenous to the model) and therefore that the level of production would be determined by demand constrained by the fixed capital in the sector. The output of the sectors is therefore demand driven, given the price fixed on the market. Since capital, too, is fixed, these sectors must hire labor to respond to an increase in demand or lay off workers and reduce intermediate consumption when demand falls.

In the model, we have five agents modeled. First, the government draws its revenues from production taxes, import duties, households' and private firms' income taxes as well as from transfers from the rest of the world (budgetary assistance). Its expenditure is made up of the consumption of public services and of transfers to other agents. We have one agent representing aggregate private firms which draw their income from capital income and pay taxes; they make transfers to other agents and save for investment. We isolated EDM for its electricity production as an agent. It draws it's income from sales of electricity. The rest of the world in considered as another agent in a standard fashion as it is used to model economic relations between Mali and the rest of the world include imports, exports and transfers to and from agents in Mali. Finally, we include a single representative household into the CGE module.

Ours is a model of a small open economy to which world prices of imports and exports are exogenous. We posed the Armington hypothesis (1969) for import demand, whereby domestic consumers can substitute domestically produced goods with imports (imperfectly) according to an elasticity of substitution that is sector specific. Where local consumers have no preference between imported and local goods, we will have a high elasticity of substitution; inversely, the elasticity of substitution is low where consumers prefer one good over the other. The relative price of the two goods is the other determinant of the ratio of demand for imported goods versus demand for local goods. On the export side, producers can sell the goods on the local market or export their production and are influenced by relative prices on each market and by their elasticity of transformation of the good for one or the other market.

Our price equations are standard other then for utilities. We used the GDP deflator as a price index, and, as stated earlier, international prices (imports and exports) are exogenous. Accordingly the country has no control over the prices applied on the world market. The only specific item in terms of prices, as mentioned earlier, is that prices for utility services are held fixed. Regulation sets this price exogenously to the model.

Our model equilibrium conditions for non utility markets are also standard. The commodity market is balanced by an adjustment of the market price of each commodity. The labor market is segmented and balances out with an adjustment of the nominal wage on each of the respective markets (skilled and unskilled). It is therefore possible for workers to move from one sector to the other, but not from one market to another. Labor supply in each of the markets is fixed, and there is no unemployment. ${ }^{7}$ The current account balance is endogenous, but both the price index and the nominal exchange rate are exogenous. With regard to the equilibrium of savings and investment, total investment adjusts to the sum of the savings of all agents in the model.

\section{Micro household module}

\footnotetext{
${ }^{7}$ This does not mean that we assume that zero unemployment in the economy but rather that unemployment is exogenous to the model.
} 
In the micro household module, we include all of the 4,966 households from the survey (EMEP). We have specified income and expenditure functions for the households; which are parameterized on the household-specific information found in the survey. As mentioned further up, the module is solved sequentially (CGE module and household module). Let us now describe this sequence. We first specify an income equation which reflects income structure for each household in the EMEP survey. We assume that the endowments of factors are exogenous. We use the factor payment variations generated by the CGE module and apply them to the factor endowments. We have twenty one factor payment variations as input into the income equation. Since capital is fixed by sector in the CGE module, we have 19 rental capital rates $\left(r_{i}\right)$ and two wage rates $(w)^{8}$. As in the CGE module, we assume that the transfers from other agents to the households are exogenous.

This procedure provides us with the new household specific income. We can then move on to the expenditure side. The important component for welfare analysis is the change in household consumption. The demand functions are derived from a utility maximization process (Cobb-Douglas utility function), and this demand equation if a function of market prices and household income. The final step in the sequential resolution of the household module consists in computing the change in welfare. Implicitly, this allows us to take into account simultaneously the income and price effects on each household's welfare $^{9}$. As in Savard (2005), we use the equivalent variation to measure the money metric change in welfare. The household-specific value shares of consumption goods observed in the survey are key elements in the welfare change.

The procedure we adopted for poverty and inequality analysis is the one commonly used with micro simulation CGE models. After identifying the target groups for the base period and simulations, ${ }^{10}$ the next step was to compute and compare poverty and inequality indexes. For poverty, we chose the $P_{\alpha}$ Foster, Greer, and Thorbecke (1984) decomposable indices ${ }^{11}$; for inequality, we chose the Gini index.

\footnotetext{
${ }^{8}$ The public service sector does not pay its capital hence the 19 rental rates of capital for the 20 production sectors.

${ }^{9}$ This approach is different from the endogenous poverty line proposed by Decaluwé et al. (2005) as it captures the price effect of the simulation through specific household preference and not through a basic needs approach. For a discussion of the advantages and disadvantages of the two approaches see Ravallion (1998).

${ }^{10}$ We decomposed our households on two basis. The first being on the level of education of the head of household and the second decomposition criteria was households connected to EDM and household not connected to the EDM network.

${ }^{11}$ The poverty indexes of de Foster, Greer, and Thorbecke (1984) are additively decomposable; as such they are useful for this analysis because they allow us to measure not only the proportion of the poor among the population but also the depth and severity of poverty. $P_{\alpha}$ indexes are calculated with the following equation:
}

$$
P_{\alpha}=\frac{1}{\sum_{i=1}^{N} w_{i}} \sum_{i=1}^{q} w_{i}\left(\frac{z-y_{i}}{z}\right)^{\alpha}
$$

where $\alpha$ is a parameter characterizing the degree of poverty aversion; $z$, the poverty line; $y_{i}$, household income; $N$, the total number of households; $w_{i}$, the sampling weight for household $i$; and $q$, the number of poor households below the poverty line. When $\alpha=0, P_{\alpha}$ represents the proportion of households in a group or in the general population below the poverty line. If $\alpha=1$, the relative weight of households below the poverty line is proportional to their incomes, which thus represents the poverty gap. For detailed information on this index family, see Ravallion (1994). 


\section{Impact analysis of electricity reform}

In this section, we focus on the impact of one likely outcome of price reforms in Mali's electricity sector and one form of compensation for poor households. We use the model described above to simulate the impact of seven scenarios on household welfare (table 2). More specifically, we analyze the impact of scenarios in which the company increases tariffs at two levels, one designed to recoup operating expenses; the other to recoup both operating and capital expenses. Because specific information on the pricing policies of the operator is not available, we present here illustrative simulations of the impact of several possible strategies, basing our assumptions on our knowledge of the strategies typically considered by private operators seeking to improve cost recovery. Our simulations are applied to two broad types of policies: (i) cost recovery alone and (ii) cost recovery accompanied by compensatory transfers to poor households.

Our first set of simulations focuses on cost recovery only. Here, we compare the impact of an increase in the recovery of operating expenditures (OPEX) with that of an increase in the recovery of capital expenditures (CAPEX) as well. For illustrative purposes, for OPEX we simulate an increase of 30 percent and for CAPEX an increase of 45 percent $^{12}$. The common wisdom is that the resulting increases in electricity tariffs will decrease the welfare of the poor households that buy electricity from EDM. The actual effects are unclear, although many critics of cost-recovery policies argue that the poor are likely to suffer relatively more than other groups from higher prices for power.

In the second type of policy simulation, we introduce a transfer program for poor households directly affected by the cost-recovery programs. The transfers are household specific, implying that the operator is allowed to rely on cross-subsidies to meet the needs of the poor. We also run a set of simulations comparing cross-subsidies to various types of tax instruments and to foreign grants as sources of financing for the transfer programs needed to mitigate the consequences of price increases. More specifically, we test (i) an increase in household income tax, (ii) an increase in the corporate income tax, and (iii) an increase in import duties and finally, we also explore a program in which the transfers are funded through foreign grants. Although the differences in impact of the various financing instruments proved to be relatively minor, we report all the results. For reference, the seven simulations are summarized in table 3.

Table 2 Definition of simulations

\footnotetext{
${ }^{12}$ The level of increase of tariffs for OPEX and CAPEX scenarios are based in figures from EDM.
} 


\begin{tabular}{lll}
\hline Simulation & $\begin{array}{l}\text { Costs to be } \\
\text { recovered }\end{array}$ & Definition \\
\hline Sim 1 & OPEX & 30 percent Increase in the price of electricity \\
Sim 2 & OPEX & $\begin{array}{l}\text { Sim } 1+\text { transfers to poor households connected to electricity grid } \\
45 \text { percent Increase in the price of electricity }+ \text { transfers to poor households connected to } \\
\text { electricity grid }\end{array}$ \\
$\operatorname{Sim} 3$ & CAPEX & Sim $3+$ personal income tax to fund transfer program \\
$\operatorname{Sim} 4$ & CAPEX & Sim $3+$ business income tax to fund transfer program \\
$\operatorname{Sim} 5$ & CAPEX & Sim $3+$ increase in import duties to fund transfer program \\
$\operatorname{Sim} 6$ & CAPEX & Sim $3+$ foreign grants to fund transfer program \\
$\operatorname{Sim} 7$ & CAPEX & \\
\hline
\end{tabular}

Table 3 Key macro results of simulations

\begin{tabular}{lrrrrrrrr}
\hline Variables & \multicolumn{1}{c}{ Base } & \multicolumn{1}{c}{$\operatorname{Sim} 1$} & $\operatorname{Sim} 2$ & $\operatorname{Sim} 3$ & $\operatorname{Sim} 4$ & $\operatorname{Sim} 5$ & \multicolumn{1}{c}{$\operatorname{Sim} 6$} & $\operatorname{Sim} 7$ \\
\hline Household income (ytm) & 149.55 & -0.78 & -0.64 & -0.94 & -0.85 & -0.91 & -1.24 & -0.87 \\
Skilled wages (s) & 1.00 & -1.57 & -2.38 & -3.53 & -1.86 & -2.05 & -1.86 & -2.11 \\
Unskilled wages (sn) & 0.50 & -0.66 & -0.66 & -0.96 & -0.97 & -1.28 & -0.97 & -1.23 \\
Government income (yg) & 30.74 & -0.33 & -0.22 & -0.31 & 1.45 & 1.45 & 1.45 & 1.45 \\
Public spending (g) & 25.60 & -0.39 & -1.40 & -2.07 & 0.00 & 0.00 & 0.00 & 0.00 \\
Current account balance (bac) & -0.81 & -6.23 & -3.59 & -4.04 & -9.39 & -9.81 & -9.28 & -24.87 \\
Business revenues (ye) & 49.28 & -0.79 & -0.69 & -1.02 & -1.23 & -1.15 & -1.23 & -1.14 \\
Electricity revenues & 21.89 & 76.58 & 76.77 & 113.80 & 113.45 & 113.61 & 113.48 & 113.39 \\
Firms' savings (se) & 31.98 & -0.95 & -0.82 & -1.22 & -1.47 & -3.38 & -1.47 & -1.37 \\
Total investment & 46.17 & 2.33 & 2.60 & 3.91 & 3.36 & 2.28 & 3.36 & 2.74 \\
Gross domestic product & 181.94 & -0.02 & -0.02 & -0.03 & -0.02 & -0.02 & -0.02 & -0.02 \\
\hline
\end{tabular}

We will briefly describe the macro and sectoral effects of the simulations before considering the impact of these policy scenarios on poverty and income distribution. We focus first on the two simulations involving recovery of operating expenses (simulations 1 and 2) before moving on to those designed to simulate the recovery of both operating and capital expenses (simulations 3-7).

\section{Simulating the recovery of operating expenses only}

Simulation 1 produces a very slight decrease in government income of -0.33 percent and similar decreases for the aggregate household income drops by -0.78 and business income which falls by -0.79 percent. The drop in income for households is mainly caused by the decrease in wage rates. Skilled wages fall by -1.57 percent; unskilled by -0.66 percent. The reduction in the rental rates of capital for non electricity sectors (18 of 19 sectors) (table 4) also put a downward pressure on household income. This reduction in rental rates of capital is at the source of the decrease in businesses income.

At the sectoral level, as expected, we observe strong capital price increases in the electricityproducing sector ( +76.58 percent) (table 4). The strongest decrease in the rental rate of capital outside the utility sector is found in transport ( -2.98 percent) and textiles $(-2.75$ percent). On the other hand, the increase in the price of electricity produces a strong drop in its demand whenever there is some demand flexibility. When the demand for electricity is determined by a Leontief function (as in the production 
sectors) the increase in price will be transmitted into an increase in production cost. This will lead to an increase in the producer price of goods that use electricity intensively in their production process.

Table 4 Variation of rental rate of capital

\begin{tabular}{llrrrrrrrr}
\hline Variable & Sector & Base & Sim 1 & Sim 2 & Sim 3 & Sim 4 & Sim 5 & Sim 6 & Sim 7 \\
\hline & Staple crops & 1.00 & -0.66 & -0.52 & -0.77 & -1.06 & -0.79 & -1.06 & -0.73 \\
& Rice & 1.00 & -1.38 & -1.21 & -1.79 & -2.16 & -1.78 & -2.15 & -1.81 \\
& Export agriculture & 1.00 & -0.72 & -0.55 & -0.81 & -1.16 & -0.90 & -1.16 & -0.74 \\
& Cotton & 1.00 & -0.21 & -0.20 & -0.31 & -0.33 & -0.31 & -0.34 & -0.42 \\
& Fishing and livestock & 1.00 & -0.27 & -0.16 & -0.23 & -0.46 & -0.42 & -0.46 & -0.34 \\
& Forestry & 1.00 & -0.26 & -0.07 & -0.10 & -0.49 & -0.37 & -0.48 & -0.34 \\
Rental rate of & Extractive industries & 1.00 & -1.30 & -1.30 & -1.96 & -1.96 & -1.94 & -1.96 & -2.30 \\
& Food industries & 1.00 & -1.31 & -1.19 & -1.76 & -2.01 & -1.71 & -2.01 & -1.69 \\
& Textile industries & 1.00 & -2.75 & -2.71 & -4.04 & -4.11 & -3.83 & -4.11 & -3.11 \\
& Other manufacturing & 1.00 & -1.04 & -0.96 & -1.46 & -1.62 & -1.95 & -1.62 & -0.73 \\
& Water nonutilities & 1.00 & -0.74 & -2.96 & -4.45 & -2.59 & -4.47 & -5.08 & -4.50 \\
& Water utilities & 1.00 & -6.64 & -6.51 & -9.77 & -10.09 & -10.08 & -10.20 & -10.15 \\
& Electricity & 1.00 & 76.58 & 76.77 & 113.80 & 113.45 & 113.61 & 113.48 & 113.39 \\
& Energy & 1.00 & -6.81 & -7.20 & -10.29 & -9.47 & -9.64 & -9.45 & -9.77 \\
& Construction & 1.00 & 1.71 & 1.88 & 2.82 & 2.48 & 1.11 & 2.48 & 1.29 \\
& Commerce & 1.00 & -1.09 & -0.93 & -1.38 & -1.71 & -1.46 & -1.71 & -1.46 \\
& Transport & 1.00 & -2.98 & -2.96 & -4.39 & -4.43 & -4.38 & -4.44 & -4.50 \\
& Telecommunications & 1.00 & -7.11 & -6.22 & -9.43 & -11.27 & -10.82 & -11.28 & -11.68 \\
& Other private services & 1.00 & -1.39 & -1.38 & -1.98 & -1.96 & -2.30 & -1.92 & -2.19 \\
& Financial services & 1.00 & -1.40 & -1.44 & -2.13 & -2.04 & -1.89 & -2.03 & -1.94 \\
\hline
\end{tabular}

At this point it is useful to highlight how the 30 percent increase in electricity prices affects other productive sectors of the economy. The sectors that benefit the most are those that use a relatively small share of electricity in production (for example, output in the construction sector rises by 1.85 percent (table 6). Only seven other sectors increase their output, most very slightly, though the output of financial services rises by 0.11 percent. Output falls the most in the transport and textiles sectors-by -1.42 percent and -1.36 percent.

After factor prices, the element that most affects household welfare following the tariff increase of simulation 1 is the price of goods and services (table 5). The exogenous 30 percent rise in the price of electricity in the simulation has a direct effect on the cost of households' consumption basket. The five other sectors experience an endogenous increase in price, with the greatest increases in transport (0.96 percent) and construction ( 0.27 percent). The strongest decreases are found in staple crops ( -0.64 percent) and rice $(-0.56$ percent). 
Table 5 Variation in market prices

\begin{tabular}{|c|c|c|c|c|c|c|c|c|c|}
\hline Variable & Sector & Base & $\operatorname{Sim} 1$ & $\operatorname{Sim} 2$ & $\operatorname{Sim} 3$ & $\operatorname{Sim} 4$ & $\operatorname{Sim} 5$ & $\operatorname{Sim} 6$ & $\operatorname{Sim} 7$ \\
\hline & Staple crops & 1.01 & -0.64 & -0.53 & -0.78 & -1.01 & -0.82 & -1.01 & -0.73 \\
\hline & Rice & 1.02 & -0.56 & -0.46 & -0.68 & -0.88 & -0.69 & -0.88 & -0.49 \\
\hline & Export agriculture & 1.09 & -0.29 & -0.21 & -0.31 & -0.47 & -0.35 & -0.47 & 0.14 \\
\hline & Cotton & 1.00 & -0.23 & -0.15 & -0.22 & -0.40 & -0.31 & -0.40 & -0.19 \\
\hline & Fishing and livestock & 1.01 & -0.14 & -0.03 & -0.03 & -0.26 & -0.24 & -0.26 & -0.12 \\
\hline & Forestry & 1.00 & -0.31 & -0.13 & -0.18 & -0.55 & -0.47 & -0.55 & -0.40 \\
\hline & Extractive industries & 1.00 & 0.35 & 0.40 & 0.60 & 0.51 & 0.34 & 0.51 & 0.46 \\
\hline & Food industries & 1.11 & -0.31 & -0.32 & -0.47 & -0.45 & -0.44 & -0.45 & -0.01 \\
\hline & Textile industries & 1.37 & 0.03 & 0.02 & 0.03 & 0.05 & 0.05 & 0.05 & 1.38 \\
\hline & Other manufacturing & 1.15 & 0.07 & 0.07 & 0.11 & 0.11 & 0.07 & 0.11 & 0.87 \\
\hline \multirow[t]{11}{*}{ Market prices } & Water nonutilities & 1.00 & -0.84 & 0.72 & 1.15 & -0.32 & 1.11 & 1.35 & 1.19 \\
\hline & Water utilities & 1.02 & 0.00 & 0.00 & 0.00 & 0.00 & 0.00 & 0.00 & 0.00 \\
\hline & Electricity & 1.01 & 30.00 & 30.00 & 45.00 & 45.00 & 45.00 & 45.00 & 45.00 \\
\hline & Energy & 1.05 & -0.01 & -0.01 & -0.01 & 0.00 & 0.00 & 0.00 & 0.19 \\
\hline & Construction & 1.02 & 0.27 & 0.24 & 0.38 & 0.43 & 0.21 & 0.43 & 0.53 \\
\hline & Commerce & 1.02 & -0.63 & -0.51 & -0.75 & -1.00 & -0.82 & -1.00 & -0.75 \\
\hline & Transport & 1.05 & 0.96 & 0.92 & 1.40 & 1.49 & 1.40 & 1.49 & 1.53 \\
\hline & Telecommunications & 1.05 & 0.00 & 0.00 & 0.00 & 0.00 & 0.00 & 0.00 & 0.00 \\
\hline & Other private services & 1.04 & 0.20 & 0.15 & 0.29 & 0.42 & 0.15 & 0.44 & 0.24 \\
\hline & Financial services & 1.01 & -0.41 & -0.69 & -1.01 & -0.43 & -0.52 & -0.43 & -0.50 \\
\hline & Public services & 1.00 & 0.30 & -0.04 & -0.03 & 0.66 & 0.55 & 0.66 & 0.67 \\
\hline
\end{tabular}

In the second simulation poor households connected to the EDM grid receive a transfer equal to the exogenous price increase. The results of this change differ only slightly from those of the previous simulation (table 3). Although the decrease in skilled wages is markedly greater, aggregate household income decreases less (by -0.64 percent instead of -0.78 percent). The same is true for other agents, which appear to lose less in this scenario. The main change comes in government expenditure, which decreases three times more than in the first simulation. The difference stems from the fact that the transfers to households are funded through a decrease in government expenditure on public services such as health, education and other services. The reduction in public services is also responsible for the steeper decrease in skilled wages, as most civil servants are skilled workers. The unskilled wage remains unchanged compared to simulation 1. Decreases in skilled wages are likely to lower the welfare of households headed by skilled workers; we will return to this point in the next section. Adding the transfer to the price increase does not greatly affect market prices (table 5) or output by sector (table 6).

We next consider five simulations in which capital expenses as well as operating expenses are recovered by EDM. Simulation 3 assumes a 45 percent increase in the price of electricity and a transfer to poor households as in the previous simulation. Although the magnitude of the effects is stronger (tables 3-6), the larger price increase does not alter the sign of the variations observed in the first two simulations for either the macro or the sectoral variables. The changes in magnitude will increase the amplitude of the changes in poverty and income distribution presented in the next section. 
Table 6 Variation in value added or output by sector

\begin{tabular}{|c|c|c|c|c|c|c|c|c|c|}
\hline Variable & Sector & Base & $\operatorname{Sim} 1$ & $\operatorname{Sim} 2$ & $\operatorname{Sim} 3$ & $\operatorname{Sim} 4$ & $\operatorname{Sim} 5$ & $\operatorname{Sim} 6$ & $\operatorname{Sim} 7$ \\
\hline & Staple crops & 215.21 & 0.01 & 0.04 & 0.06 & 0.00 & 0.07 & 0.00 & 0.08 \\
\hline & Rice & 64.66 & -0.08 & -0.05 & -0.07 & -0.14 & -0.06 & -0.14 & -0.06 \\
\hline & Export agriculture & 21.29 & 0.01 & 0.03 & 0.05 & 0.01 & 0.03 & 0.01 & 0.03 \\
\hline & Cotton & 63.49 & 0.02 & 0.03 & 0.05 & 0.03 & 0.04 & 0.03 & 0.04 \\
\hline & Fishing and livestock & 212.59 & 0.03 & 0.04 & 0.06 & 0.04 & 0.07 & 0.04 & 0.07 \\
\hline & Forestry & 100.07 & 0.03 & 0.05 & 0.07 & 0.04 & 0.07 & 0.04 & 0.07 \\
\hline & Industries extractives & 206.35 & -0.04 & -0.02 & -0.03 & -0.08 & -0.05 & -0.08 & -0.08 \\
\hline & Food industries & 55.15 & -0.20 & -0.04 & -0.07 & -0.40 & -0.11 & -0.40 & -0.12 \\
\hline & Textile industries & 9.60 & -1.36 & -1.00 & -1.52 & -2.24 & -1.81 & -2.25 & -1.20 \\
\hline & Other manufacturing & 43.27 & 0.01 & 0.08 & 0.12 & -0.03 & -0.05 & -0.03 & 0.15 \\
\hline \multirow[t]{11}{*}{ Value added or output } & Water nonutilities & 1.28 & 0.00 & -1.40 & -2.13 & -1.00 & -2.05 & -2.64 & -2.10 \\
\hline & Water utilities & 10.24 & 0.00 & 0.00 & 0.00 & 0.00 & 0.00 & 0.00 & 0.00 \\
\hline & Electricity & 26.63 & 0.00 & 0.00 & 0.00 & 0.00 & 0.00 & 0.00 & 0.00 \\
\hline & Energy & 1.71 & -1.56 & -1.55 & -2.23 & -2.24 & -2.23 & -2.23 & -2.26 \\
\hline & Construction & 116.21 & 1.85 & 2.12 & 3.18 & 2.61 & 1.85 & 2.62 & 1.96 \\
\hline & Commerce & 308.74 & -0.01 & 0.00 & 0.00 & -0.01 & 0.00 & -0.01 & 0.00 \\
\hline & Transport & 56.28 & -1.42 & -1.31 & -1.96 & -2.18 & -1.96 & -2.18 & -2.06 \\
\hline & Telecommunications & 37.52 & 0.00 & 0.00 & 0.00 & 0.00 & 0.00 & 0.00 & 0.00 \\
\hline & Other private services & 95.56 & -0.18 & -0.10 & -0.13 & -0.27 & -0.30 & -0.26 & -0.26 \\
\hline & Financial services & 17.94 & 0.11 & 0.77 & 1.15 & -0.21 & 0.11 & -0.21 & 0.11 \\
\hline & Public services & 161.23 & -0.69 & -1.36 & -2.04 & -0.66 & -0.55 & -0.66 & -0.67 \\
\hline
\end{tabular}

We will analyze the last four simulations simultaneously. As a group they explore the best way to generate the income necessary to finance transfers to poor households while holding government expenditure constant. The results of the four simulations differ very little at the macro and even at the sectoral level. Because the transfers to the poor households connected to EDM's grid do not represent a very large sum, the increases in various taxes and transfers necessary to fund the program generate limited general equilibrium effects. Funding the transfer program through foreign grants (simulation 7) shows the strongest differences from the other simulations.

Comparing simulations 4-7 with simulation 3, in which the transfer program is funded through a reduction in government expenditure on public services, we note that aggregate household income decreases less in three cases-personal income tax (simulation 4), business income tax (simulation 5), and foreign aid (simulation 7) — than in the case where import duties fund the transfers (simulation 6) (table 3). The unskilled wage decreases by more in simulations 5 and 7 than in the other two. In all four cases the skilled wage decreases less. That is an expected result of holding public expenditure constant in these scenarios, which attenuated the effect on the market for skilled labor. In the simulations where the transfers were funded by personal income taxes (simulation 4) and import duties (simulation 6) the reduction is the smallest ( -1.86 percent in both cases). The gap between the two wages is much smaller in simulations $4-7$ (where it ranges from 0.77 percent to 0.89 percent) than in simulation 3 , where the gap is 2.57 percent. This difference will greatly influence the distributive effect of these scenarios. Government income increases by 1.45 percent in simulations $4-7$, reflecting the implicit cost of the transfer program. 
Business income decreases more in simulations 4-7 than in simulation 3; those simulations are negatively biased toward firms and positively biased toward households and government.

At the sectoral level, we concentrate on market prices (table 5) and the rental rate of capital (table 4 ), as these are the key transmission variables between policies and poverty changes. The quantitative changes in prices induced by simulations 4-7 are quite limited, with the exception of simulation 7. However, we observe some qualitative changes in market prices in two cases. The sectors concerned are industrial agriculture (positive in simulation 7 and negative in simulations 3-6) and the non utilities water sector (negative in simulation 4; positive in simulations 5-7). In general the price effect is stronger in the last four simulations. The rental rate of capital shows greater quantitative differences from one simulation to another, but no changes of sign. On average the quantitative effects are greater in simulations 4-7 than in simulation 3.

\section{Income distribution and poverty}

In this section we analyze the changes in poverty and income distribution at the national level under each of the seven simulated policy scenarios. We decompose households based according to two criteria:

- Level of education of the head of the household

- Whether households received water and electricity from EDM.

We first look at the changes in poverty indices at the national level before moving on to the decomposition analysis.

Simulation 1, which generated a decrease in aggregate household income, also produces increases in the poverty headcount, depth, and severity indexes of 0.41 percent, 0.61 percent, and 0.74 percent, respectively (table 7). The larger increase in poverty headcount in the second simulation is somewhat surprising, since that simulation included a transfer to poor households affected by the increase in electricity tariffs. However, the skilled wage decreased steeply between simulations 1 and 2, and this appears to override the impact of the transfers. As the households concerned are probably near the poverty line, the depth and severity indexes change little from simulation 1 to simulation 2.

Table 7 Variation in poverty indexes at the national level, by simulation

\begin{tabular}{lllllllll}
\hline \multicolumn{1}{l}{ Simulation } \\
\hline Index & Base & 1 & 2 & 3 & 4 & 5 & 6 & 7 \\
Poverty headcount (FGT-0) & 0.64 & 0.41 & 0.73 & 0.50 & 0.82 & 1.07 & 0.77 & 0.82 \\
Depth of poverty (FGT-1) & 0.29 & 0.61 & 0.65 & 0.61 & 0.90 & 1.21 & 0.88 & 0.99 \\
Severity of poverty (FGT-2) & 0.16 & 0.74 & 0.81 & 0.74 & 1.09 & 1.42 & 1.07 & 1.24 \\
\hline
\end{tabular}

Source: Indexes are those of de Foster, Greer, and Thorbecke (1984).

This situation is a signal that the general equilibrium effects generated by the two simulations have a greater impact on poverty than do the price increases and transfer programs. In the second group of simulations (in which both capital and operating expenses are recovered), the simulation in which the transfers are funded through a decrease in public services (simulation 3) generates the lowest increases in poverty along all three poverty indexes. It will be interesting to see if our conclusions are altered by 
analyzing changes in poverty according to the educational level of the head of household and the source of the household's water and electricity.

As we use an empirical distribution to compute the poverty headcount index, we often obtain weak or no effects, because too few households in any given category can be observed around the poverty line. For example, households headed by an individual with a secondary education are unaffected in six of the seven simulations when using the poverty headcount index (table 8). In this context the poverty depth and severity indices are much more informative.

Table 8 Variation in poverty headcount (FGT 0 ) by level of education of head of household and household's source of water and electricity

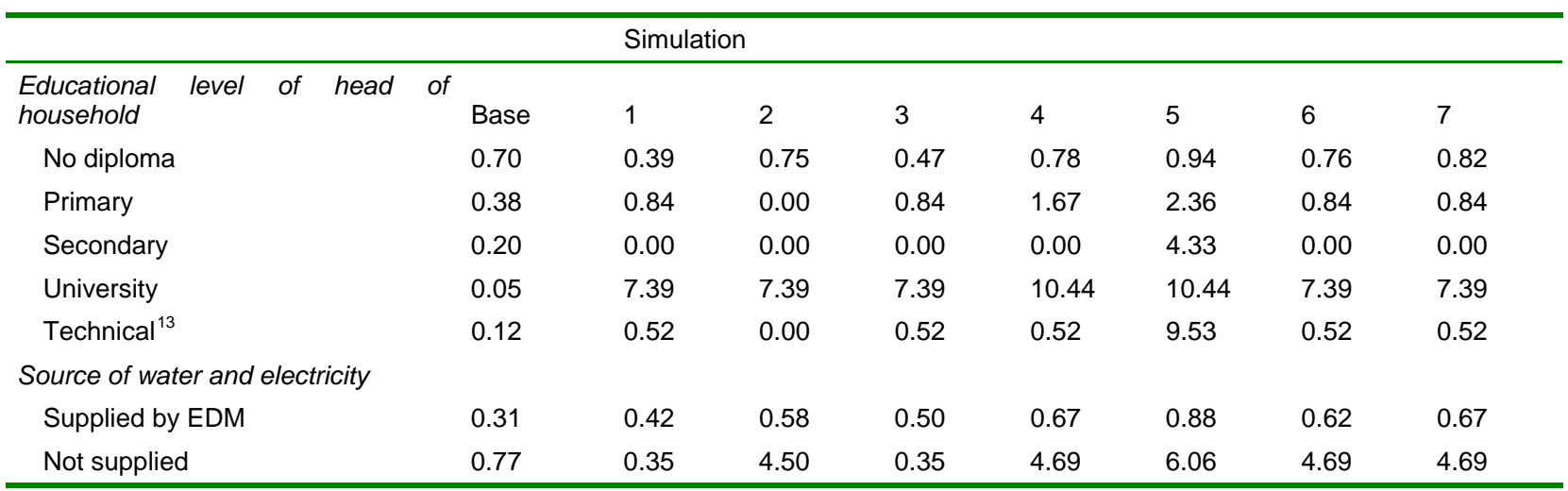

The first simulation produces an increase in poverty headcount for all groups except the secondary-level group. The poverty ratio increases more for the households supplied by EDM than for those not supplied, but the difference is not great. The impact of the tariff increase on the group not supplied can be interpreted as the general equilibrium impact of the policy. The result for the connected households combines the direct and general equilibrium effects. However, looking at changes in the depth and severity of poverty (tables 9 and 10), the effects conform more closely to our expectations. In those cases, households supplied by EDM experience much greater increases in poverty (three times greater).

With regard to the level of education of the head of household, the largest poverty increase in poverty headcount is found in households headed by someone with a university degree (table 8). This is not surprising, since a large share of this group consumes electricity from the grid, and the baseline poverty level is low. The poverty headcount ratio for this group rises from 5.00 percent to 5.37 percent-a 7.39 percent increase in the poverty ratio.

\footnotetext{
${ }^{13}$ Technical training refers to all forms of education post secondary and non university. A broad range of training is included in this category.
} 
Table 9 Variation in depth of poverty (FGT 1) by level of education of head of household and household's source of water and electricity

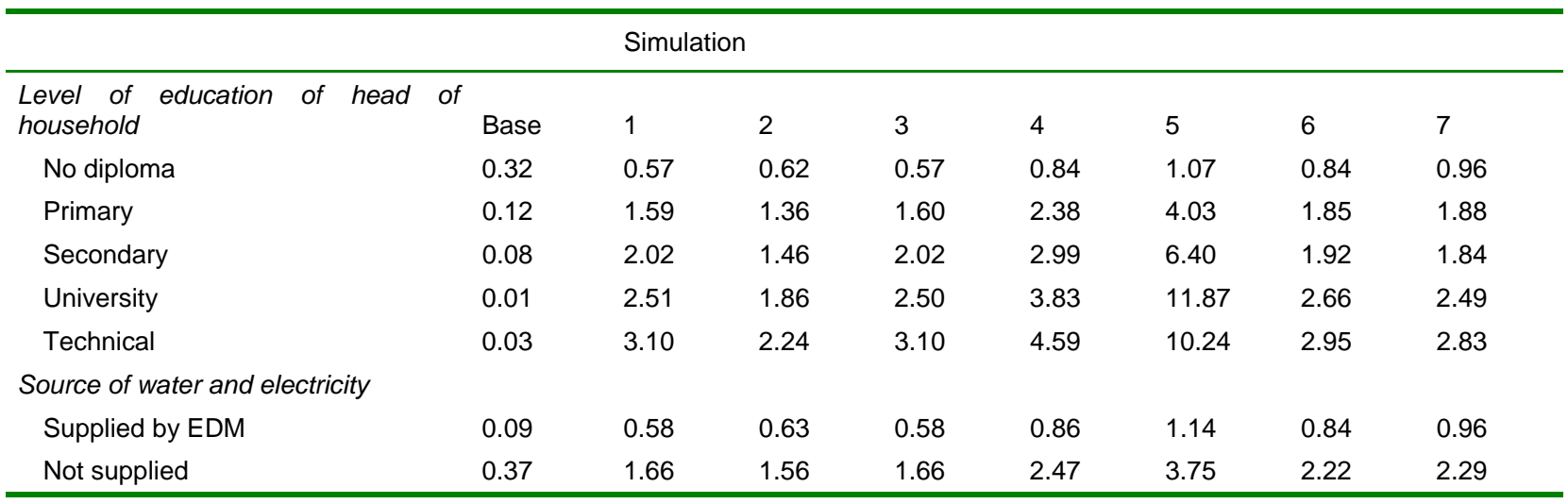

Turning now to the indexes of depth and severity of poverty, we note that the most educated households are most negatively affected by increases in the price of electricity, implying that the direct effect of the increase is more important for these indexes than it was for the headcount ratio. In these two cases households headed by someone with a technical degree are most negatively affected by the increase in tariffs. Holders of university degrees come second.

In the second simulation, we observe an interesting result in the poverty headcount among households headed by holders of a technical degree and those headed by someone with a primary school education (table 8). In both cases, the increase in poverty in simulation 1 is cancelled out, whereas for the other three groups no change is observed. Considering households by the source of their power and water, it is interesting that the transfer program added in simulation 2 has a negative effect on the poverty headcount of both connected and unconnected households (table 8). However, for the group supplied by EDM the difference from simulation 1 to simulation 2 is quite small, whereas the unconnected group sees its poverty ratio rise from 0.35 percent to 4.5 percent.

The addition of the transfer program in simulation 2 brings about a decrease in the depth and severity of poverty for all household groups except one. Households headed by someone with no education experience an increase in poverty (tables 9 and 10). The starkest drop in depth and severity is seen among households whose head holds a university or technical degree. For the same indexes we surprisingly observe a very small increase in poverty among those supplied by EDM and a slight decrease in poverty among the households not supplied. Once again this shows that the general equilibrium income price effects of the transfer program are greater than its direct effect. For simulation 3, the negative effects are stronger for all groups with the exception of households with no education compared to simulation 2. This situation is valid for the depth and severity indexes.

We turn now to the impact of the different strategies for funding the transfer program. In simulations 4-7, the poverty headcount index produces ambiguous results (table 8). Only among the uneducated group does the poverty headcount increase over simulation 3 in all cases. And only simulation 5 (transfers funded from business income tax) produces a change in the headcount for all groups. None of the four funding methods is clearly preferable, at least when using the headcount ratio. When viewed in light of the depth and severity of poverty, however, the results are clearer. We will concentrate on the poverty depth index (table 9), but the trends are the same for the two indexes. As with the headcount 
index, uneducated households lose in all four scenarios, compared with simulation 3. The primary education group is also negatively affected in simulations 4-7. In simulations 6 and 7, the secondary and technical education groups benefit from a reduction in poverty compared with simulation 3 . The university-educated group benefits very slightly from simulation 7 compared to simulation 3 . With the poverty depth index, Simulation 7, wherein the transfer program is paid for by an increase in foreign aid, is the best of the lot, improving the poverty status of three of the five education groups. In the case of the poverty severity index, the result are reversed for the secondary education group with a slight increase in poverty compared to simulation 3. Hence, in the case of poverty severity, it is still the foreign aid option which is the most favorable even if it is not as favorable as for the poverty depth index.

With households broken down by source of power and water, all three poverty indexes show the same trend. Simulations 4-7 all produce an increase in poverty, with the effect being particularly strong among households not supplied by EDM.

Table 10 Variation in severity of poverty (FGT 2) by level of education of head of household and household's source of water and electricity

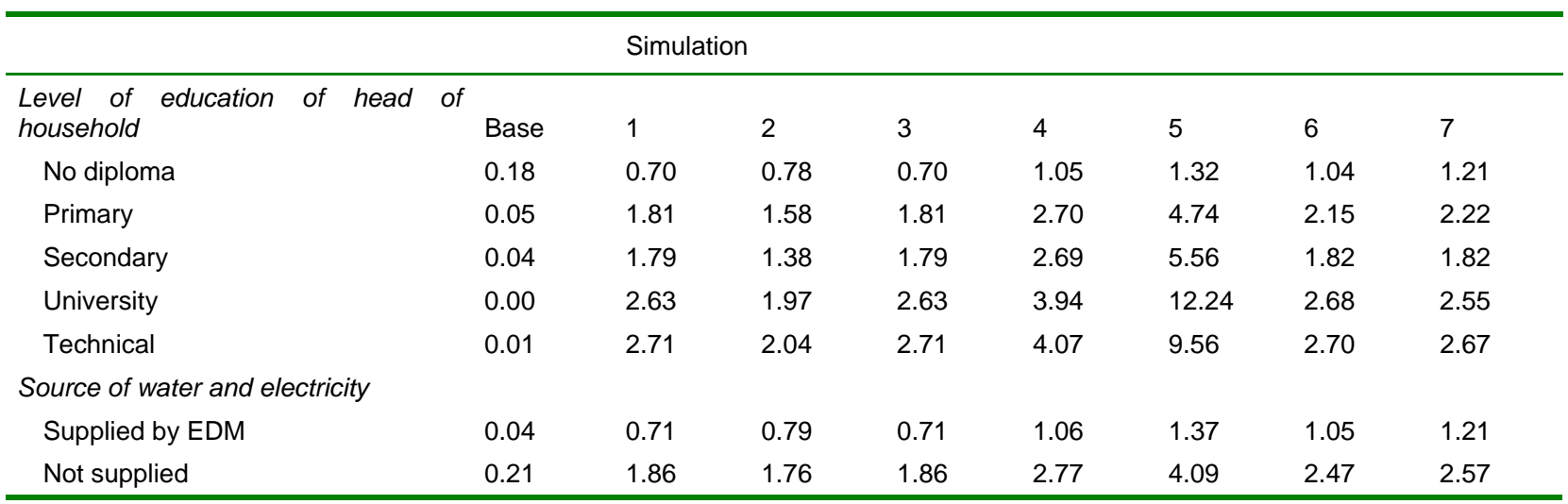

The funding policy that produces the greatest negative impact on both groups (supplied and not supplied) is the business income tax (simulation 5). The policy that produces the least negative effect for both groups is import duties (simulation 6). There results are valid for either the poverty depth or poverty severity indexes.

To analyze changes in income distribution we used the Gini index. Variations in the index for Mali as a whole and for subgroups of the population are presented in the table 11. 
Table 11 Variation in Gini index by level of education of head of household and household's source of electricity

\begin{tabular}{|c|c|c|c|c|c|c|c|c|}
\hline & & Simula & & & & & & \\
\hline Decomposition & Base & 1 & 2 & 3 & 4 & 5 & 6 & 7 \\
\hline National & 0.41 & -0.16 & -0.08 & -0.16 & -0.24 & -0.60 & -0.12 & -0.07 \\
\hline \multicolumn{9}{|l|}{ Education } \\
\hline Within-group inequalities & 0.15 & -0.59 & -0.28 & -0.59 & -0.87 & -2.21 & -0.38 & -0.24 \\
\hline Between groups nequalities & 0.26 & 0.08 & 0.03 & 0.08 & 0.12 & 0.30 & 0.03 & 0.02 \\
\hline No diploma & 0.39 & -0.05 & -0.03 & -0.05 & -0.08 & -0.18 & -0.06 & -0.03 \\
\hline Primary & 0.33 & -0.06 & -0.06 & -0.06 & -0.08 & -0.07 & -0.09 & -0.08 \\
\hline Secondary & 0.32 & 0.15 & 0.07 & 0.15 & 0.23 & 0.58 & 0.09 & 0.07 \\
\hline University & 0.35 & 0.01 & 0.04 & 0.01 & 0.02 & 0.11 & 0.03 & 0.09 \\
\hline Technical & 0.31 & 0.03 & 0.02 & 0.03 & 0.05 & 0.36 & 0.02 & 0.02 \\
\hline \multicolumn{9}{|l|}{ Source of electricity } \\
\hline Within-group inequalities & 0.22 & -0.36 & -0.17 & -0.36 & -0.53 & -1.43 & -0.24 & -0.13 \\
\hline Between groups nequalities & 0.19 & -0.07 & -0.04 & -0.07 & -0.10 & -0.22 & -0.06 & -0.04 \\
\hline Supplied by EDM & 0.35 & -0.13 & -0.07 & -0.13 & -0.19 & -0.42 & -0.10 & -0.07 \\
\hline Not supplied by EDM & 0.37 & -0.11 & -0.01 & -0.11 & -0.16 & -0.67 & 0.00 & 0.04 \\
\hline
\end{tabular}

The first observation concerning the changes in income distribution induced by the simulations is that the effects are relatively small. The second general observation is that all of the simulated policies reduce inequalities at the national level. When analyzing the first three simulations, we note very little change in the groups decomposed by education. The strongest effect is found in the secondary-education group in simulations 1 and 3, where inequality increases by 0.15 percent. Between-group changes appear to be more important for these simulations, for both breakdowns.

Simulations 4-7 exhibit stronger distribution effects than simulations 1-3. In all four simulations, the inequality decreases for the two least-educated groups and the inequality increases for the others. The fifth simulation (business income tax) is the one exhibiting the strongest distributional effects were the least educated group benefits from this policy and the three most educated groups are disadvantaged by it. When the population is broken down by electricity supply, we observe a decrease in inequality for nearly all groups and all simulations.

Our scenarios generated some interesting results. First, the general equilibrium effects of the simulated reforms seem to exceed the direct effects with regard to poverty and income distribution. This is explained by two facts: (1) only 10.5 percent of Mali's households are connected to the electricity grid, and (2) poor households make up a very small share of those connected (see table 1). The connected households in the six poorest deciles, for example, make up just 2.2 percent of the population. It is difficult to generate strong effects on poverty indexes by acting on so few poor households.

However, the tariff increases modeled here have a significant impact on wages and prices, and these general equilibrium effects translate into non-negligible effects on poverty. In terms of income 
distribution, the simulated reforms appear to have very little effect, except when a business income tax is used to fund the transfer program (simulation 5). The transmission mechanism at play here is a steep reduction in investment, which affects the construction sector.

\section{Conclusion}

\section{[[This is more of a summary than a conclusion.]]}

We used a CGE microsimulation sequential (MSS) model customized to reflect conditions in Mali to analyze the effect of price reform in the electricity sector on poverty and income distribution in the country. The CGE-MSS approach proposed by Chen and Ravallion (2004) was the approach best suited to address the data-reconciliation problems we faced. We also investigated the likely effects of transfers designed to compensate the poor for increased electricity tariffs, as well as the effects of alternative means of funding those transfers. Because no SAM was available for Mali, we built one.

In our first three scenarios, involving price increases of either 30 or 45 percent, the main winner is EDM, which see its income increase significantly. All other agents see their income decrease as a result of these reforms. In simulations were government fund the transfer programs via different sources, its situation improves. The main sources of the growth in poverty are lower wages and lower rental rates for capital held by households. The reduction in wages can be traced to layoffs at the government level and at EDM electricity utility unit. Laid-off workers reentering the labor market take jobs at lower wages.

The increase in the electricity tariff does not affect poverty directly, because very few poor households are connected to the electricity grid (table 1), and because households decrease their consumption of electricity in response to the price increase. Moreover, household groups are not affected in the same way. Urban households and educated households are the most negatively affected by the price increases because they are the largest consumers of electricity and are most likely to be skilled workers, whose wages deteriorate the most following the reform.

In a second set of scenarios (simulations 4-7) all economic agents come up losers-with the exception of EDM and government. The households and firms are almost equally affected. Our results also show that general equilibrium price (goods, services and factors) dominate the direct price effects of the reform in terms of poverty and distribution effect.

The bottom line is that price increases are very favorable for the electricity sector but generate increases in poverty for all groups, even when the transfer programs are implemented. Because households not connected to the grid receive no transfers but suffer from the general equilibrium effects of the price increases, they are the biggest losers from the reform. But transfers funded by taxes do not improve the situation even of the small number of poor people who are connected to the grid. This surprising result is explained by the negative price effects of the transfer program. The wage effect is also negative, because reducing public expenditure entails layoffs of skilled workers and downward pressure on skilled wages.

The other methods of funding the transfer program (through higher customs duties or larger foreign grants) exert greater negative pressure on unskilled wages. Therefore their impact is stronger on poor households, the majority of which depend on unskilled wages. In fact, the wage effects of the reform 
overwhelm the transfer program. Again, the small number of poor households connected to the grid explains the negligible direct effects of all of the scenarios.

Our results highlight the potential impact of price increases in the context of privatization of utilities. The results of the distribution analysis presented in the first section reveal a very dramatic fact: most poor households are not connected to the electricity grid. That being so, it is not surprising that the poor do not suffer directly from price increases, but they do suffer, sometimes greatly, from the general equilibrium effects of those increases. Reforms of the electricity sector should include an aggressive program to connect more poor households to the grid, and that effort should be combined with alternative targeting policies to compensate the poor, not only for the direct effects of price increases, but also for negative general equilibrium effects of needed reforms. 


\section{References}

Andersen, L. E., and R. Faris. 2002. "Natural Gas and Income Distribution in Bolivia." Andean Competitiveness Project Working Paper. Instituto de Investigaciones Socio-Económicas, Catholic University of Bolivia, La Paz, and Center for International Development, Harvard University. February.

Armington P. S. 1969. “A Theory of Demand for Products Distinguished by Place of Production. IMF Staff Paper 16, International Monetary Fund, Washington, DC.

Benitez, D., O. Chisari, and A. Estache. 2003. "Can the Gains from Argentina’s Utilities Reform Offset Credit Shocks?” In C. Ugaz and C. Waddams Price (eds.), Utility Privatization and Regulation: A Fair Deal for Consumers? (175-202). Northampton, MA: Edward Elgar.

Bourguignon F., A. S. Robilliard, and S. Robinson. 2005. "Representative Versus Real Households in the Macroeconomic Modeling of Inequality.” In T. J. Kehoe, T.N. Srinivasan, and J. Whalley (eds.), Frontiers in Applied General Equilibrium Modeling. Cambridge: Cambridge University Press.

Bourguignon, F., and A. Spadaro. 2005. "Microsimulation as a Tool for Evaluating Redistribution Policies.” Working Paper 2005-02, University of Paris-Charles Jourdain, Department of Economic Sciences.

Bourguignon F. and L. Savard (2007), Macro-micro modeling with a Top-down/bottom-up approach with endogenous labor supply in BOURGUIGNON, F. et L.A. PEREIRA DA SILVA, "Evaluating the Impact of Macroeconomic Policies on Poverty and Income Distribution - Vol. II” World Bank and Oxford University Press. Forthcoming.

Chen, S., and M. Ravallion. 2004. Welfare Impacts of China's Accession to the World Trade Organization. World Bank Economic Review 18(1): 29-57.

Chisari, O., A. Estache, and C. Romero. 1999. "Winners and Losers from Privatization and Regulation of Utilities : Lessons from a General Equilibrium Model of Argentina.” World Bank Economic Review 13(2): 357-378.

Cockburn, J. 2001. "Trade Liberalization and Poverty in Nepal: A Computable General Equilibrium Microsimulation Analysis.” Cahier de Recherche 01-18, CREFA, University of Laval, Québec.

Cogneau, D., and A.-S. Robilliard. 2000. "Income Distribution, Poverty and Growth in Madagascar: Micro Simulations in a General Equilibrium Framework.” IFPRI TMD Discussion Paper 61, International Food Policy Research Institute, Washington, DC.

Decaluwé, B., J.-C. Dumont, and L. Savard. 1999. "How to Measure Poverty and Inequality in General Equilibrium Framework.” Working Paper 9920, CREFA, University of Laval, Québec.

Decaluwé, B., A. Martens, and L. Savard. 2001. La politique economique du développement et les modèles d'equilibre général calculable. Montréal: Montréal University Press.

Decaluwé B., Y. Dissou, and A. Patry. 2001. "Union douanière au sein de l'UEMOA: une analyse quantitative.” Revue Économique 52(4): 811-830.

Dervis K., J. de Melo, and S. Robinson. 1982. General Equilibrium Models for Development Policy. London: Cambridge University Press. 
Estache, A. 2005a. "How Much Do We Know about Sub-Saharan Africa's Infrastructure and the Impacts of Its 1990 Reforms?” Paper presented at the Cape Town Conference on Private Participation in Infrastructure, Economic Growth, and the Poor in Africa, June.

Estache, A. 2005b. “On Latin America’s Infrastructure Experience: Policy Gaps and the Poor.” In J. Nellis and N. Birdsall (eds.), Reality Check: The Distributional Impact of Privatization in Developing Countries (281-296). Center for Global Development, Washington, DC.

Foster J., J. Greer, and E. Thorbecke. 1984. “A Class of Decomposable Poverty Measures.” Econometrica 52(3): 761-766.

Gørtz, M., G. Harrison, C. Neilsen, and T. Rutherford. 2000. Welfare gains of extending opening hours in Denmark. Economic working paper B-00-03, University of South Carolina, Darla Moore School of Business, Columbia, South Carolina.

Hertel, T., and J. Reimer. 2004. "Predicting the Poverty Impacts of Trade Reform.” World Bank Policy Research Working Paper 3444, Washington, DC.

Huppi, M., and M. Ravallion. 1991. “The Sectoral Structure of Poverty During an Adjustment Period: Evidence for Indonesia in the Mid-1980s. World Development 19(2): 1653-1678.

Löfgren, H., R. Doukkali, H. Serghini, and S. Robinson. 1997. "Rural Development in Morocco: Alternative Scenarios to the Year 2000.” IFPRI TMD Discussion Paper 17, International Food Policy Research Institute, Washington, DC.

Ministère du plan et de l'aménagement du territoire (MPAT-DNSI), (2004), Enquête malienne sur l'évaluation de la pauvreté (EMEP) : Principaux résultats, Bamako.

McCulloch, N., A. Winters and X. Cirera (2002) Trade Liberalization and Poverty: A Handbook, London: Centre for Economic Policy Research and Department for International Development.

Navajas, F. 2000. "El impacto distributive [[distributivo?]] de los cambios en los precios relativos en la Argentina entre 1988-1998 y los efectos de las privatizaciones y la desregulación económica.” In La Distribution del Ingreso en la Argentina. Buenos Aires Fundación de Investigaciones Económicas Latinoamericanas.

Rutherford, T., D. Tarr, and O. Shepotylo. 2005. "Poverty Effects of Russia’s WTO Accession: Modeling 'Real' Household and Endogenous Productivity Effects.” World Bank Policy Research Working Paper 3473, Washington, DC.

Savard, L. 2003. "Poverty and Income Distribution in a CGE Household Sequential Model.” Paper presented at WIDER Conference on Poverty, Inequality and Welfare, Helsinki, May.

Savard, L. 2005. "Poverty and Inequality Analysis within a CGE Framework: A Comparative Analysis of the Representative Agent and Microsimulation Approaches. Development Policy Review 23(3): 313-332. 